\title{
Copulation Release Pheromone, Erectin, from the Azuki Bean Weevil (Callosobruchus chinensis L.)
}

\author{
Kaoru Tanaka, Kanju Ohsawa, Hiroshi Honda and Izuru Yamamoto \\ Laboratory of Pesticide and Bio-organic Chemistry, \\ Tokyo University of Agriculture, Setagaya-ku, Tokyo 156, Japan
}

(Received September 6, 1980)

\begin{abstract}
Erectin, a pheromone of the azuki bean weevil, Callosobruchus chinensis L., which induces the male to extrude his genital organ and to attempt copulation, was found to consist of two synergistically acting fractions, neither having any activity. One was a mixture of several hydrocarbones: 3-methylpentacosane, 11-methylheptacosane, 3-methylheptacosane, 11-methylnonacosane, 13-methylnonacosane, 11,15-dimethylnonacosane, 13methylhentriacontane, 9,13-dimethylhentriacontane and 11,15-dimethyltritriacontane; the other was a dicarboxylic acid, (E)-3,7-dimethyl-2-octene-1,8-dioic acid. This copulation release pheromone was distinct from the female sex attractant and was released from both sexes, but affected only the male.
\end{abstract}

\section{INTRODUCTION}

The azuki bean weevil is a persistent pest insect of the azuki bean, cowpea and other important beans. The chemical bases for its various types of behavior have been partially identified: sex attraction, ${ }^{1,2)}$ host preference, ${ }^{3,4)}$ oviposition, ${ }^{5-8)}$ and development. ${ }^{9-11)}$

It was shown that a female weevil, dead or alive, was capable of both attracting and causing copulation in the male, although her sex attractant alone, when separately offered, did not cause him to attempt copulation.

Now we have discovered that the sex pheromone which affects its mating behavior is actually composed of two pheromones, each with its own activity: a sex attractant and a copulation release pheromone. This paper details the isolation and identification of the copulation release pheromone which elicits the copulation behavior of the male weevil.

\section{EXPERIMENTAL}

\section{Gas-liquid Chromatography ( $g l c)$}

Apparatus, Shimadzu GC 6A; column, $2 \mathrm{~m} \times$ $3 \mathrm{~mm}$ i.d., glass; carrier gas, nitrogen $(40 \mathrm{ml} /$ min); detector, FID. Other conditions were:

\begin{tabular}{lllll}
\hline & \multicolumn{4}{c}{ Conditions } \\
\cline { 2 - 5 } & \multicolumn{1}{c}{1} & \multicolumn{1}{c}{2} & 3 & 4 \\
\hline Support & Shimarite W & Shimarite $\mathrm{W}$ & Uniport $\mathrm{HP}$ & Uniport HP \\
& $60-80$ mesh & $60-80$ mesh & $60-80$ mesh & $60-80 \mathrm{mesh}$ \\
Stationary phase & $\mathrm{OV}-1,1 \%$ & $\mathrm{OV}-1,1 \%$ & $\mathrm{PEG}-\mathrm{HT}, 5 \%$ & $\mathrm{PEG}-\mathrm{HT}, 5 \%$ \\
Oven temperature & $230-260^{\circ} \mathrm{C}$ & $120-300^{\circ} \mathrm{C}$ & $165-225^{\circ} \mathrm{C}$ & $70-240^{\circ} \mathrm{C}$ \\
Programming & $2^{\circ} \mathrm{C} / \mathrm{min}$ & $8^{\circ} \mathrm{C} / \mathrm{min}$ for & $10^{\circ} \mathrm{C} / \mathrm{min}$ & $10^{\circ} \mathrm{C} / \mathrm{min}$ \\
& & 6 min, then & & \\
\hline
\end{tabular}

For preparative $g l c$, FID was replaced by a capillary tube $(15 \mathrm{~cm} \times 1 \mathrm{~mm})$ which, when needed, was further inserted into hexane in a microtube. 


\section{Gas Chromatography-Mass Spectrometry (GC-MS)}

Apparatus, Shimadzu Auto GCMS-6020; column, $2 \mathrm{~m} \times 2 \mathrm{~mm}$ i.d., glass; support, Uniport HP, 60-80 mesh; stationary phase, PEG-HT $5 \%$; carrier gas, He $(20 \mathrm{ml} / \mathrm{min})$. For temperature programming two conditions were used: condition $1,190^{\circ} \mathrm{C}$; condition 2, $60^{\circ} \mathrm{C}$ for $7.5 \mathrm{~min}$, then $60-160^{\circ} \mathrm{C}\left(16^{\circ} \mathrm{C} / \mathrm{min}\right)$. Ion source temperature, $280^{\circ} \mathrm{C}$; electron energy, $20 \mathrm{eV}$; accelerating voltage, $3.5 \mathrm{kV}$; trap current, $60 \mu \mathrm{A}$.

\section{Azuki Bean Weevils (Callosobruchus chin- ensis $L$.)}

The weevils were maintained on azuki bean (Dainagon from Hokkaido) at $27^{\circ} \mathrm{C}, \mathrm{RH} 70 \pm$ $5 \%$.

\section{Mating Behavior}

In order to know the chemicals which control insect behavior a prerequisite is to identify the behavior of the target insect in detail. It is also important to establish a bioassay method which fully reflects this behavior. We have therefore studied the mating behavior of the azuki bean weevil. This is illustrated in Fig. 1.

A male (either standing still or walking) when in the proximity of a female raised his antennae and ran toward her in a zigzag pattern. A flying male hovered over a female, then would land and run toward her in the same zigzag pattern. As he contacted the female, he lowered his antennae and tried to bend his head. The female would sometimes

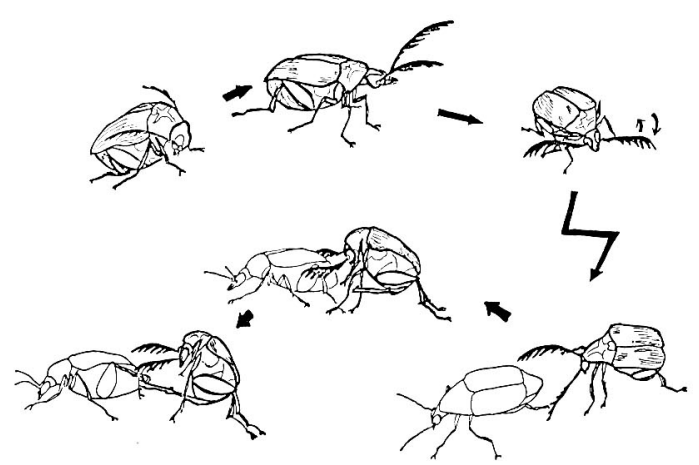

Fig. 1 Mating behavior of azuki bean weevil, Callosobruchus chinensis. take several forward steps, but the male followed her with his antennae lowered. When she stopped, the male bent his head, extended the tip of his abdomen toward the female and extruded his genital organ. The female raised her abdomen slightly and accepted his organ, thereby establishing copulation. We have termed the behavior which took place from the stationary, walking or flying position to the zigzag walking as "sex attraction," and that from the lowering of the antennae to the extrusion of the genital organ as "copulation release."

\section{Bioassay Method}

Males 3-4 days after emergence were used for bioassay; they had been separated from females since within 24 hours after their emergence. One day before the test males in groups of four were put into glass vessels 2.4 $\mathrm{cm}$ in diameter and $4.5 \mathrm{~cm}$ in height and were kept in a room at $27^{\circ} \mathrm{C}$ and $\mathrm{RH} 70 \pm 5 \%$. With a syringe, a test sample was applied to the tip of a glass rod $3 \mathrm{~mm}$ in diameter and $15 \mathrm{~cm}$ in length. The tip of the rod was then brought near the male; if he approached in a zigzag manner and crisscrossed the rod several times, the sample was judged to have attractancy. If he tried to extrude his genital organ and to attempt to copulate with the rod, the sample was also judged to have copulation release (CR) activity (Fig. 2). When a male was not attracted to the sample offered, the tip of the rod was brought into contact with his head several times to see whether or not $\mathrm{CR}$ activity was present. We

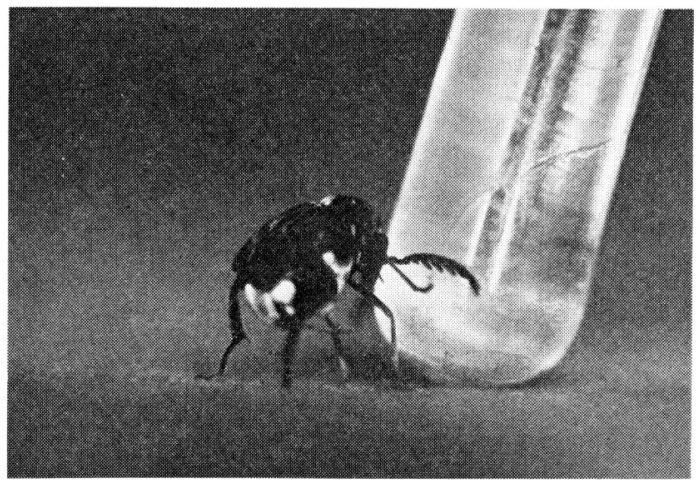

Fig. 2 Response of male C. chinensis to "Erectin" on a glass rod. 
replicated one experiment more than four times, each time using 20 males. For convenience, when the positive response in a $2 \mathrm{~min}$ period was below $20 \%$ the symbol (-) is used, for over $20 \%$ and below $40 \%$ the symbol is $( \pm)$, for over $40 \%$ and below $80 \%(+)$ is used, and over $80 \%$ is shown by $(++)$.

\section{Recognition of Copulation Release Pher- omone}

Females were collected immediately after their emergence from azuki beans which had been deposited on 25 days earlier. A group of several hundred virgin females was placed in petri dishes $9 \mathrm{~cm}$ in diameter and $6 \mathrm{~cm}$ in height with folded filter paper and kept in a room at $27^{\circ} \mathrm{C}, \mathrm{RH} 70 \pm 5 \%$ for 5 days. To trap the organic volatiles, clean air was passed through the insect rearing vessel and then through Porapak Q. Males were attracted to these virgin females and copulated. Even after the females had been killed by freezing, the males were attracted and tried to copulate with the dead bodies (Table 1).

When virgin females were submitted to ether extraction for 15 hours using a Soxhelet extractor, the males showed no interest in the female body which remained. This indicated that the chemicals which usually elicited the mating behavior in the male were no longer present. The extract from a virgin female's body, therefore, could have been ex-

Table 1 Attractancy and copulation release activity of female azuki bean weevil, C. chinensis, and the extracts.

\begin{tabular}{|c|c|c|c|c|}
\hline \multirow[t]{2}{*}{ Sample } & \multicolumn{2}{|c|}{$\begin{array}{l}\text { Attract- } \\
\text { ancy } \\
\text { Dose* }\end{array}$} & \multicolumn{2}{|c|}{$\begin{array}{c}\mathrm{CR} \\
\text { activity } \\
\text { Dose* }\end{array}$} \\
\hline & 0.1 & 1 & 0.1 & 1 \\
\hline 1. Virgin female & & $H$ & & H \\
\hline 2. The dead body & & $H$ & & H \\
\hline $\begin{array}{l}\text { 3. The body after extrac- } \\
\text { tion }\end{array}$ & & - & & - \\
\hline 4. The extract of 2 & + & \pm & - & \pm \\
\hline $\begin{array}{l}\text { 5. Extract from container } \\
\text { and filter paper }\end{array}$ & $H$ & $H$ & + & $H$ \\
\hline $\begin{array}{l}\text { 6. The extract } 5 \text { after } \\
\text { heating }\end{array}$ & - & - & + & $H$ \\
\hline $\begin{array}{l}\text { 7. The volatile from } 1 \\
\text { (Porapak Q extract) }\end{array}$ & H & H & - & - \\
\hline
\end{tabular}

* Equivalent amount of the indicated female. pected to contain such stimulant; however, the extract was very stick and, though it provoked some attractancy, the male showed little CR activity.

On the other hand, the ether extract of the filter paper and the absorbent cotton, which had been used to wipe the glass vessel, showed both strong attractancy and CR activity. This was proven by the male being attracted to the sample-coated glass rod and trying to copulate with it by extruding his gential organ.

The above ether extract from the filter paper and the glass vessel, when warmed at $90^{\circ} \mathrm{C}$ under an air stream (4-5 liter $\left./ \mathrm{min}\right)$ for $24 \mathrm{hrs}$, lost its attractancy though still retaining strong CR activity. This clearly showed that different chemicals are involved in sex attraction and copulation release, the former being the volatile substance and the latter being of low volatility and stable to heat and air oxidation; we have termed this latter "Erectin." The organic volatile trapped by Porapak $Q$ from air passing through the insect rearing vessel had a strong attractancy.

\section{Collection and Fractionation of Copulation Release Pheromone, Erectin-Multiplicity of the Pheromone Component}

The ether extract from the filter paper and glass vessel, with (B) or without (A) having been dried under an air stream as mentioned, was fractionated into a neutral-basic fraction and an acidic fraction using $0.1 \mathrm{~N} \mathrm{NaOH}$ (Table 2). Starting from extract A, the presence of attractive component was indicated in the neutral-basic fraction or its $15 \%$ etherhexane eluate from a Florisil column chromatography. Though not shown as a peak, the attractive fractions from Porapak $Q$ and $15 \%$ ether-hexane gave the same Rt on a glc. Further works on the sex attractant will be reported elsewhere.

Starting from extract B, both the neutralbasic and the acidic fractions showed almost no $\mathrm{CR}$ activity. When recombined, however, the original CR activity was recovered. Therefore, the copulation behavior of the male is due to the synergistic action between the neutral-basic fraction and the acidic fraction.

The neutral-basic fraction was submitted to 
Table 2 Attractancy and copulation release activity of the fractions from the extract from female $C$. chinensis.

\begin{tabular}{|c|c|c|c|}
\hline \multirow{2}{*}{ Sample } & \multicolumn{2}{|c|}{$\begin{array}{l}\text { Attract- } \\
\text { ancy* }\end{array}$} & \multirow{2}{*}{$\frac{\begin{array}{c}\mathrm{CR} \\
\text { activity* }\end{array}}{\mathrm{B}}$} \\
\hline & A & $\mathrm{B}$ & \\
\hline 1. Whole extract** & $H$ & - & $H$ \\
\hline 2. Neutral-basic fraction & $H$ & - & - \\
\hline 3. Acidic fraction & - & - & - \\
\hline 4. $2+3$ & $H$ & - & H \\
\hline 5. Hexane elute of 2 & - & - & - \\
\hline 6. $5+3$ & - & - & $H$ \\
\hline $\begin{array}{l}\text { 7. } 5 \% \text { Ether-hexane } \\
\text { elute of } 2\end{array}$ & - & - & - \\
\hline 8. $7+3$ & - & - & - \\
\hline $\begin{array}{l}\text { 9. } 15 \% \text { Ether-hexane } \\
\text { elute of } 2\end{array}$ & H & - & - \\
\hline 10. $9+3$ & H & - & - \\
\hline $\begin{array}{l}\text { 11. } 2 \% \text { Methanol-ether } \\
\text { elute of } 2\end{array}$ & - & - & - \\
\hline 12. $11+3$ & - & - & - \\
\hline 13. $5+9+3$ & $H$ & - & $H$ \\
\hline
\end{tabular}

A: Starting from the extract 1, B: Starting from air-dried extract 1 .

* Dose: 1 female equivalent, ** Extract from container and filter paper.

Florisil column chromatography to effect further fractionation. When these fractions were individually combined with the acidic fraction, only the eluate with hexane showed a level of activity equal to the original.

The hexane eluate was then further fractioned by glc on OV-1 (condition 1) (Fig. 3). Each fraction $(\mathrm{A}-\mathrm{N})$, was combined with the acidic fraction, and each portion then appeared to contribute to the synergistic activity in proportion to its quantity (Table 3 ). The amount of the hexane eluate was about 12 $\mu_{\mathrm{o}}$ per female ( 5 days after emergence).

For fractionation of the acidic fraction, the methylated product with diazomethane was submitted to glc on OV-1 (condition 2) in order to obtain several fractions (Fig. 4). Each fraction was hydrolyzed with $1 \mathrm{ml}$ of $1 \mathrm{~N} \mathrm{KOH} / 90 \% \mathrm{MeOH}$ by warming it at 80 $85^{\circ} \mathrm{C}$ for 1 hour, during which time $1 \mathrm{ml}$ of methanol was added every 10 minutes. The reaction mixture was-concentrated, water added, made acidic with $20 \% \mathrm{HCl}$ and extracted with ether. The hydrolyzed fraction was then combined with the neutral-basic fraction to
Table 3 Copulation release activity of gas chromatographic fractions obtained from the hexane elute, when combined with the acidic fraction.

\begin{tabular}{|c|c|c|}
\hline \multicolumn{2}{|c|}{ Sample } & \multirow{2}{*}{$\begin{array}{c}\begin{array}{c}\mathrm{CR} \\
\text { activity* }\end{array} \\
H\end{array}$} \\
\hline Hexane elute & + acidic $\mathrm{fr}$. & \\
\hline Fraction A & + acidic $\mathrm{fr}$. & - \\
\hline Fraction $\mathrm{B}$ & + acidic fr. & + \\
\hline Fraction $\mathrm{C}$ & + acidic $\mathrm{fr}$ & \pm \\
\hline Fraction D & + acidic fr. & + \\
\hline Fraction $\mathrm{E}$ & + acidic fr. & + \\
\hline Fraction $\mathrm{F}$ & + acidic fr. & \pm \\
\hline Fraction G & + acidic fr. & - \\
\hline Fraction $\mathrm{H}$ & + acidic fr. & + \\
\hline Fraction I & + acidic fr. & + \\
\hline Fraction $\mathrm{J}$ & + acidic fr. & - \\
\hline Fraction $\mathrm{K}$ & + acidic fr. & + \\
\hline Fraction $\mathrm{L}$ & + acidic fr. & + \\
\hline Fraction $\mathrm{M}$ & + acidic fr. & \pm \\
\hline Fraction $\mathrm{N}$ & + acidic fr. & + \\
\hline \multicolumn{2}{|c|}{ Acidic fraction } & - \\
\hline \multicolumn{2}{|c|}{$\begin{array}{l}\text { Rt } 3.8 \text { min peak (Condition } 2 \text { ) + hexane } \\
\text { elute }\end{array}$} & H \\
\hline \multicolumn{2}{|c|}{$\begin{array}{l}\text { Rt } 5.2 \text { min peak (Condition } 3 \text { ) +hexane } \\
\text { elute }\end{array}$} & $H$ \\
\hline
\end{tabular}

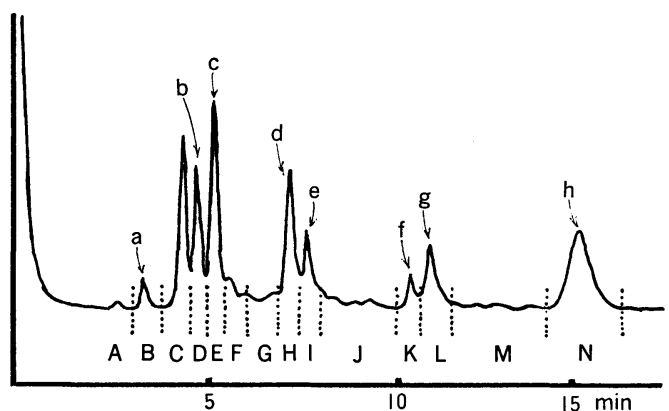

Fig. 3 Gas-liquid chromatogram of hexane elute of the extract from container and filter paper for female $C$. chinensis and fractions for testing copulation release activity.

GLC condition 1. Identification of peak $\mathrm{a}-\mathrm{h}$ : see text.

determine the CR activity.

The activity centered at one peak (Rt: 3.8 min) between methyl laurate and methyl myristate which was isolated and further submitted to glc on PEG-HT (condition 3). The 


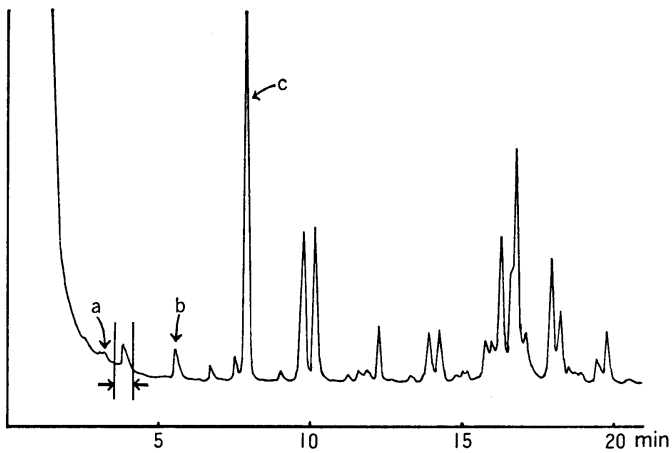

Fig. 4 Gas-liquid chromatogram of methylated acidic fraction of the extract from container and filter paper for female $C$. chinensis and a region of copulation release activity shown by combination with the hexane elute.

GLC condition 2. a: Methyl laurate, b: Metyl myristate, c: Metyl palmitate.

activity again centered at the single major peak which appeared between methyl myristate and methyl palmitate (Rt: $5.2 \mathrm{~min}$ ). This peak was regarded as the methyl ester of a copulation release acidic component. We have termed the acid "Callosobruchusic acid" or C-acid. The amount of $\mathrm{C}$-acid is about 15 ng per female ( 5 days after emergence). The mixture of $\mathrm{C}$-acid and hexane eluate showed the same degree of $\mathrm{CR}$ activity as the extract from the filter paper and the glass vessel (Table 3).

\section{Chemical Nature of Erectin}

The CR pheromone is composed of two fractions, one being eluated with hexane and the other being acidic.

1) Hexane eluate: This fraction was found to be composed of a mixture of hydrocarbons, almost all of which have been identified. ${ }^{7,8)}$ The hydrocarbons which were relatively strong in synergistic activity to the acidic fraction were: 3-methyl-pentacosane (a), 11-methylheptacosane(b), 3-methylheptacosane(c), 11-methylnonacosane and 13-methylnonacosane (d), 11, 15-dimethylnonacosane (e), 13-methylhentriacontane (f), 9,13-dimethylhentriacontane (g) and 11,15-dimethyltritriacontane (h) (Fig. 3).

2) C-Acid from the acidic fraction: C-acid methyl ester separated from $g l c$ on OV-1 was subjected to several reactions and analyzed by $\mathrm{GC}-\mathrm{MS}$, using several $\mu \mathrm{g}$ for each reaction.

a) Hydrogenation product: One $\mathrm{ml}$ acetone solution of the sample was added to 10 $\mathrm{mg}$ of $\mathrm{Pd}$ on charcoal. $(10 \%)$, hydrogen gas $\left(3 \mathrm{~kg} / \mathrm{cm}^{2}\right)$ was passed for 50 seconds and the vessel was tightly closed and shaken for 30 minutes. The product was submitted to glc on PEG-HT (condition 3) and the peak of the product almost overlapped with the peak of the authentic methyl myristate. The molecular weight was 230 , as determined by CIMS. EI-MS (Fig. 5) showed characteristic fragmentation for dicarboxylic acid dimethyl ester (M-31, M-59, M-64, M-73, M-91 and M-105). Each fragmentation was assigned to be $\mathrm{M}-\mathrm{X}$ where $\mathrm{X}$ is $\mathrm{OCH}_{3}, \mathrm{COOCH}_{3},\left(\mathrm{OCH}_{3}\right)_{2}+$ $2 \mathrm{H}, \quad \mathrm{CH}_{2} \mathrm{COOCH}_{3}, \quad \mathrm{COOCH}_{3}+\mathrm{OCH}_{3}+\mathrm{H}$, $\mathrm{CH}_{2} \mathrm{COOCH}_{3}+\mathrm{OCH}_{3}+\mathrm{H}$ which suggested the presence of dicarboxylic dimethyl ester moiety. From the base peak (88) it is assumed that there is a methyl group on the carbon adjacent to the carboxyl group.

b) Mass spectrum of C-acid methyl ester: CI-MS indicated the molecular weight of 228 and the hydrogenated product gave the molecular weight of 230 , indicating that there is one double bond.

c) Ozonolysis products: C-acid methyl ester was dissolved in pentane $(500 \mu \mathrm{l})$ which was cooled to about $-20^{\circ} \mathrm{C}$ by dry ice. Ozone in air was introduced through a glass tube with a narrow opening which had been inserted into the vessel for 5 or 10 minutes. Zinc
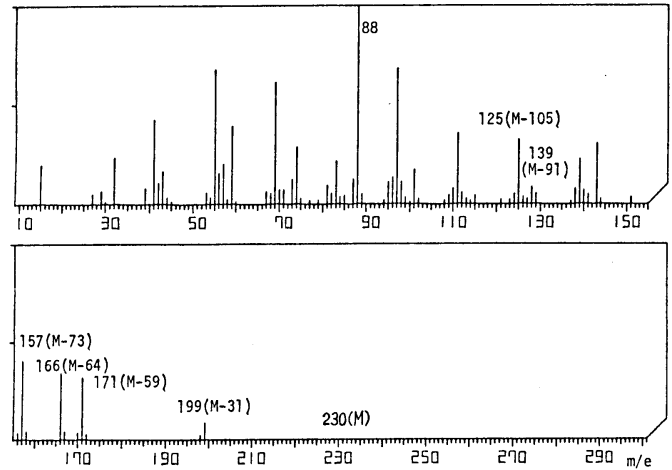

Fig. 5 Mass spectrum of hydrogenation product of $\mathrm{C}$-acid methyl ester. GC--MS condition 1. 


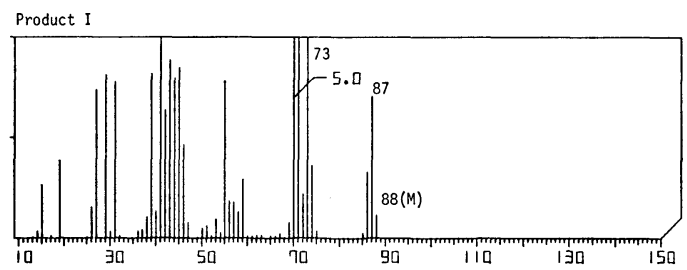

Product II
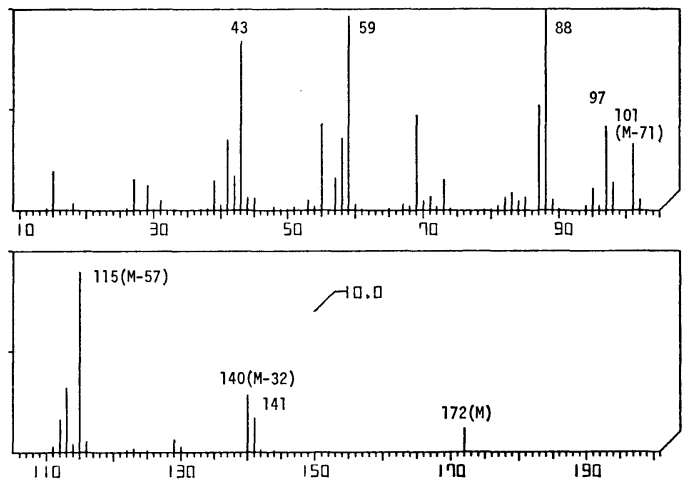

Fig. 6 Mass spectra of ozonolysis products of C-acid methyl ester.

powder $(50 \mathrm{mg})$ and distilled water $(500 \mu \mathrm{l})$ were put into another micro-tube; the reaction mixture was added to this tube in two or three portions and shaken vigorously. The resulting mixture was extracted with ether and the extract was analyzed by glc on PEGHT (condition 4) and GC-MS. There were major peaks, products I and II.

Product I (Rt: $1.6 \mathrm{~min}$ ) showed almost the same Rt as that of hexanal. Product II (Rt: $9.6 \mathrm{~min})$ showed a little earlier Rt than expected for tridecanal. MS of products I and II are shown in Fig. 6. If we assume that Cacid is dicarboxylic acid, the only possible formulae for products I and II, as calculated from their molecular weight obtained by $\mathrm{CI}-$ MS, are $\mathrm{C}_{3} \mathrm{H}_{4} \mathrm{O}_{3}$ (MW 88) and $\mathrm{C}_{9} \mathrm{H}_{16} \mathrm{O}_{3}$ (MW 172), respectively. The only possible chemical structure for product I is, accordingly, methyl glyoxalate.

Product II must have a carbonyl group which is derived from a double bond by ozonolysis. Higher aldehydes usually do not give a parent peak; however, product II did give such a peak. Therefore, product II is most probably a ketone and the peaks 43 and
115 were assigned to be $\mathrm{CH}_{3} \mathrm{CO}^{+}$and $\left[\mathrm{M}-\mathrm{CH}_{2}\right.$ $\left.\mathrm{COCH}_{3}\right]^{+}$. The base peak was 88, suggesting the presence of a methyl group on the carbon which is adjacent to the methoxycarbonyl group. Between two possible alternatives, A and $\mathrm{B}, \mathrm{A}$ is preferred, because product II showed a strong peak at $101(\mathrm{M}-71)$ or [M$\left.\mathrm{CH}_{2} \mathrm{CH}_{2} \mathrm{COCH}_{3}\right]^{+}$, which is not expected for B.<smiles>COC(=O)C(C)CCCC(C)=O</smiles>

(A)<smiles>COC(=O)C(C)C(C)CC(C)=O</smiles>

(B) a)

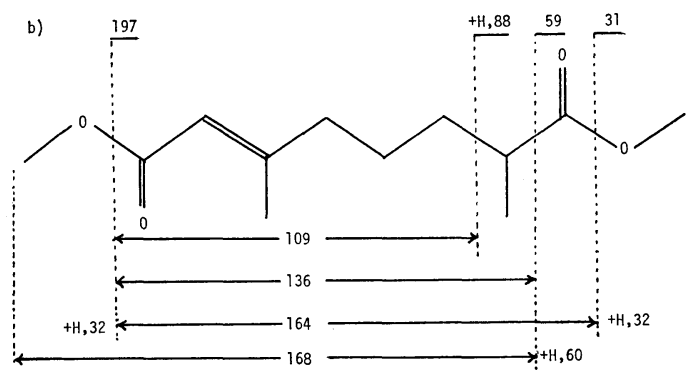

Fig. 7 Mass spectral assignments for product II (a) and C-acid methyl ester (b).
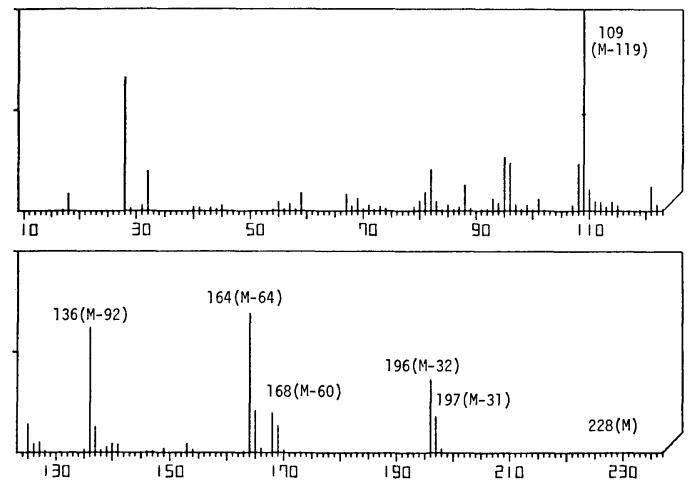

Fig. 8 Mass spectrum of C-acid methyl ester. 
Assignment of various peaks for product II is shown in Fig. 7-a.

d) Possible chemical structure for $\mathrm{C}$-acid: Combining the possible structures for the ozonolysis products I and II, the only possible structure for the methyl ester is as shown (Fig. 7-b), which explains the EI-MS (Fig. 8).

Therefore, the chemical structure of $\mathrm{C}$-acid is determined as 3,7-dimethyl-2-octene-1,8dioic acid.<smiles>CC(=CC(=O)O)CCCC(C)C(=O)O</smiles>

\section{DISCUSSION}

The presence of copulation release pheromones has been indicated in several cases. These are often distinct from sex attractants but sometimes function as sex attractants.

The male grass grub beetle, Costelytra zealandica, is attracted and attempts to copulate with paraffin dummies which have been treated with phenol released by the female, as well as with one another. ${ }^{12)}$

The female of Trogoderma glabrum releases an airborne pheromone which elicits the process of mating behavior. (E)--14-methyl-8hexadecenal as the primary component elicits both arousal and attempt to copulation from the male and the latter response is synergized by a minor component, $n$-hexanoic acid. This acid is found in both sexes and is probably responsible for the homosexual behavior of the males. ${ }^{13)}$

Females of the Pacific coast wireworm, Limonius canus, contain two sex pheromones, one being hexanoic acid which serves as a sex attractant, and the other a branched unsaturated carboxylic acid of about 10 carbon atoms acting as a copulation release pheromone. ${ }^{14)}$

Three hydrocarbons obtained from both sexes of the confused flour beetle, Tribolium confusum, 1-pentadecene, $n$-hexadecane and 1-heptadecene, increase the frequency of copulation when placed in the beetle population, affecting the male only. ${ }^{15}$

A more complex case is described for the yellow mealworm, Tenebrio molitor. The copulation release pheromone from the female consists of two synergistically acting fraction, each having only low activity. They are not identified, but one fraction seems to be an unsaturated carboxylic acid. The pheromone is produced by both sexes but affects only the male. ${ }^{16,17)}$ There are also male and female sex attractants, though unidentified. ${ }^{18,19)}$

In our case of the azuki bean weevil, the copulation release pheromone, Erectin, is distinct from the sex attractant, and is found to be a mixture of two synergistically acting fractions, each chemically identifiable. Reviewing these cases, it is interesting to realize that such simple chemicals as hydrocarbons and carboxylic acids are involved in copulation release activity. It is not uncommon to observe males of the azuki beean weevil attempting copulation with other males. This phenomenon is also observed for $T$. molitor, $T$. castaneum, $T$. confusum, Zophobas rugipes (cited in 16) and T. glabrum. ${ }^{13}$ ) Erectin was also found in the male azuki bean weevil and is a probable basis for its behavior. ${ }^{20)}$

The synthesis of $\mathrm{C}$-acid will be reported elsewhere. Only one of the two geometrical isomers, the $\mathrm{E}$ form, was identical with the natural C-acid. However, the absolute configuration for the chiral center has not yet been assigned.

To our knowledge, this paper is the first which has reported the identification of chemicals involved only in copulation release activity.

\section{REFERENCES}

1) K. Oshima, H. Honda \& I. Yamamoto: Presented at the Annual Meeting of Japanese Society of Applied Entomology and Zoology in Shizuoka, April 1972

2) H. Honda \& I. Yamamoto: Presented at International Symposium on Insect Pheromones and Their Applications in Nagaoka, Dec. 1976

3) V. G. Gokhale \& B. K. Srivastava: Experientia 29, 630 (1973)

4) V. G. Gokhale: Report to Japan Society for the Promotion of Science for Foreign Researchers, Sept. 1979

5) K. Oshima, H. Honda \& I. Yamamoto: Agric. Biol. Chem. 37, 2679 (1973)

6) H. Honda, K. Oshima \& I. Yamamoto: Pro- 
ceedings of the USA-Japan Seminar on Stored Product Insect, p. 116, 1976

7) H. Honda, A. Sakai \& I. Yamamoto: Presented at 4th International Congress of Pesticide Chemistry in Zürich, July 1978

8) A. Sakai, H. Honda \& I. Yamamoto: Presented at Annual Meeting of the Agricultural Chemical Society of Japan in Fukuoka, April 1980

9) S. Ishii: Bull. Natl. Inst. Agric. Sci. Ser. C, No. 1, 185 (1952)

10) S. W. Applebaum, U. Tadmor \& H. Podler: Entomol. Exp. Appl. 13, 61 (1970)

11) D. H. Janzen, H. B. Juster \& J. E. Liener: Science 192, 795 (1976)

12) R. F. Henzell \& M. D. Lowe: Science 168, 1005 (1970)

13) R. E. Greenblatt, W. E. Burkholder, J. C. Cross, R. C. Byler \& R. M. Silverstein: J. Chem. Ecol. 2, 285 (1976)

14) L. I. Butler, L. M. McDonough, J. A. Onsager \& B. J. Landis: Environ. Entomol. 4, 229 (1975)

15) R. Keville \& P. B. Kannowski: J. Insect Physiol. 21, 81 (1975)

16) W. R. Tschinkel: Ann. Entomol. Soc. Am. 63, 626 (1970)

17) W. Tschinkel, C. Willson \& H. A. Bern: $J$.
Exp. Zool. 164, 81 (1967)

18) G. M. Happ: Nature 222, 180 (1969)

19) G. M. Happ \& J. Wheeler: Ann. Entomol. Soc. Am. 62, 846 (1969)

20) K. Tanaka, K. Osawa, H. Honda \& I. Yamamoto: in preparation

要約

\section{アズキゾウムシの交尾フェロモン}

田中 薰, 大沢貫寿, 本田 博, 山本 出 エレクチンはアズキゾウムシの雄の交尾器を突出させ て交尾を誘導するフェロモンであり，単独では活性のな い二つの区分の共力作用によるものである。一つの区分 は数種の炭化水素, 具体的には 3-メチルペンタコサン, 11-メチルヘプタコサン, 3-メチルヘプタコサン, 11-メ チルノナコサン，13-メチルノナコサン，11，15-ジメチ ルノナコサン，9，13-ジメチルヘントリアコンタンおよ び 11,15-ジメチルトリトリアコンタンからなり，いま 一つの区分は一種のジカルボン酸, (E)-3,7-ジメチル2-オクテン-1,8-二酸からなる.この交尾フェロモンは 此からも雄からも得られるが, 雄にしか活性を呈しな W. 